Päivi Rissanen ${ }^{1)}$ ja Merja Perkiö-Mäkelä ${ }^{1)}$

1) Kuopion aluetyöterveyslaitos, PL 93, 70701 KUOPIO, etunimi.sukunimi@ttl.fi

\title{
Toiminnallisuus ja työn fyysinen kuormittavuus pihattonavetoissa
}

\section{Johdanto}

Tilakoon kasvu on muuttanut maatalousyrittäjän työympäristöä ja työmenetelmiä. Karjakoon kasvaessa on siirrytty parsinavetoista pihattoihin. Pihatossa arvioidaan kahden työntekijän pystyvän hoitamaan 60 lypsävän karjan (Klemola ym. 2000).

Suuren karjan päivittäinen hoitaminen sisältää samana toistuvia yläraajojen työliikkeitä, erityisesti selkää kuormittavia työasentoja ja raskaiden taakkojen käsittelyä. Myös tietotekniikan hyödyntäminen karjanhoitotyön eri vaiheissa asettaa vaatimuksia työympäristön ergonomialle. Maataloustyö on riskiammatti tuki- ja liikuntaelinvaivojen, erilaisten vammojen ja työkyvyttömyyden suhteen (Notkola ym. 1995; Pinzke 1997). Tuki- ja liikuntaelinvaivat ovat epidemiologisten tutkimusten mukaan yhteydessä työn fyysisiin kuormitustekijöihin (Gustafsson ym. 1994; Hildebrandt 1995; Stål ym. 1996).

Tämän tutkimuksen tavoitteena oli selvittää isojen pihattojen toiminnallisuutta ja työn fyysistä kuormittavuutta. Erityisesti haluttiin selvittää lypsytyön sekä ruokinta- ja puhdistustöiden fyysistä kuormittavuutta.

\section{Aineisto ja menetelmät}

Tutkimuksessa oli mukana 20 keskisuurta tai suurta pihattonavettaa Keski-Pohjanmaalta ja PohjoisSavosta. Pihatot oli rakennettu tai peruskorjattu vuosina 1995-2001.

Pihattojen turvallisuustasoa ja toiminnallisuutta selvitettiin havainnoimalla työskentelyä ja työympäristöä sekä haastattelemalla isäntäväkeä. Havainnoinnin runkona käytettiin kotieläintilojen työolojen kehittämiseen laadittua tarkistuslistaa (Työterveyslaitos 2000).

Fyysisen kuormittavuuden mittauksiin osallistui 20 iältään 29-45-vuotiasta maatilan isäntää ja emäntää. Tutkittavat olivat terveitä eli heillä ei ollut työ- ja toimintakykyä haittaavia pitkäaikaissairauksia, akuuttia tuki- ja liikuntaelinoiretta tai säännöllistä lääkitystä. Lypsyn, ruokintatöiden ja parsien puhdistuksen fyysistä kuormittavuutta selvitettiin sydämen sykintätaajuuden (HR), työasentojen (OWAS), lihasten sähköisen aktiivisuuden (EMG) ja koetun kuormittumisen (RPE ja VAS) mittauksilla, jotka tehtiin kunkin koehenkilön osalta yhden iltalypsyn aikana (kesto keskimäärin 2 tuntia). Kyselyllä selvitettiin maatalousyrittäjien koettua työkykyä, terveydentilaa, pitkäaikaissairastavuutta, kuntoliikunnan harrastamista ja työn ruumiillista rasittavuutta.

\section{Tulokset ja tulosten tarkastelu}

\section{Toiminnallisuus}

Pihaton pohjaratkaisu määrittää toimintojen alueet ja kulkureitit. Tutkimuspihatoista löytyi kolmenlaisia pohjaratkaisuja:

- I-muotoisia, joissa yksi suora ruokintapöytä kulki eläinhallin läpi

- L-muotoisia, joissa ruokintapöytä teki 90 asteen mutkan tai joissa oli kaksi toisiaan vastaan kohtisuorassa olevaa ruokintapöytää

- H-muotoisia, joissa oli kaksi samansuuntaista ruokintapöytää eri rakennusrungoissa.

Pohjaratkaisultaan selkeimpiä olivat I-muotoiset pihatot, joissa ruokintapöytä kulki eläinhallin poikki päädystä päätyyn jakaen eläinhallin lypsylehmien osastoon ja nuorkarjan osastoon. Peruskorjatuissa Ipihatoissa laajennusosa ja sen rehunjakojärjestelmä oli saatu liittymään saumattomasti vanhaan navetan osaan. Useimmissa peruskorjatuissa pihatoissa oli rinnakkaisia rehunjakojärjestelmiä, jotka eivät niveltyneet toisiinsa. Joissakin pihatoissa jouduttiin jakamaan rehua myös käsin. Toisiinsa niveltymättömät rehunjakomenetelmät ja rehujen jako käsin lisäsivät huomattavasti työmäärää ja työn fyysistä kuormittavuutta. 
Useimmilta tiloilta puuttuivat asianmukaiset säilytystilat. Lääkkeitä ja kemikaaleja varten tarvitaan lukollinen kaappi. Myös työvaatteille olisi oltava oma kaappi. Työvälineet voi nostaa lattialta seinälle telineeseen, josta ne ovat kätevästi saatavilla eivätkä aiheuta kompastumisvaaraa. Ruokintapöydällä ei pidä säilyttää ylimääräisiä tavaroita.

Kulkureiteissä havaittuja ongelmia olivat mm. sokkeloisuus, ahtaus sekä karjanhoitajan ja lehmien kulkureittien kohtaaminen. Kulkureittien järjestämiseen olisi kiinnitettävä erityistä huomiota. Puhtaat ja likaiset alueet olisi pyrittävä pitämään erillään, ts. toimistohuoneesta ja maitohuoneesta olisi päästävä puhtain jalkinein lypsyasemalle ja ruokintakäytävälle. Lehmäliikenne olisi ohjattava siten, etteivät eläinten ja ihmisten kulkureitit risteäisi. Eläinten joukossa liikkuminen sisältää aina tapaturmavaaran.

Kokonaisuutena ottaen tutkimuspihatot olivat keskimääräistä siistimpiä. Pienet yksityiskohdat, kuten esimerkiksi vasikoiden virikelelut, kertoivat työssä viihtymisestä. Samoin toimistohuoneiden kahvinkeittimet, iloisenväriset ikkunaverhot ja pöytäliinat sekä seinille ripustetut lasten piirrokset viittasivat siihen, että työympäristön viihtyisyyteen oli kiinnitetty huomiota.

\section{Fyysinen kuormittavuus}

Iltalypsy ja siihen liittyvät työt olivat hengitys- ja verenkiertoelimistön osalta kevyttä tai keskiraskasta työtä. Karjanhoitajien selkä oli kumarassa ja/tai kiertyneenä viidenneksen työajasta ja yläraajojen kohoasentoja oli 15\% työajasta. Vasikoiden ruokinnassa ja parsien puhdistuksessa selän kumaria ja/tai kiertyneitä työasentoja oli lähes joka kolmas havainnoista. Lypsytyö kuormittaa erityisesti ranteen ojentajalihaksia. Naisilla suhteellinen lihaskuormitus oli lypsytyön eri vaiheissa korkeampi kuin miehillä. Rasitusoireita koettiin yleisimmin niska-hartiaseudun lihaksissa. Oireita oli erityisen runsaasti naisilla kehon oikealla puolella. Maatalousyrittäjät kokivat terveydentilansa ja työkykynsä hyväksi ja suurin osa koki työnsä jonkin verran ruumiillisesti rasittavaksi.

Iltalypsy ja siihen liittyvät työt ovat hengitys- ja verenkiertoelimistön osalta kevyttä tai keskiraskasta työtä. Sydämen sykintätaajuudet olivat naisilla matalampia kuin aiemmissa tutkimuksissa parsinavetoissa (Ahonen ym. 1990), miehillä samalla tasolla. Raskain työvaihe oli hiehojen ruokinta. Tämä johtunee pääosin siitä, että useimmilla tiloilla hiehot oli sijoitettu vanhaan navettarakennukseen ja ruokintatöitä ei oltu koneellistettu toisin kuin oli lehmien ruokinta. Kasvatettaessa lehmämäärää olisi kiinnitettävä huomiota myös nuorenkarjan hoitotöihin.

Lypsyn alku ja -lopputöissä esiintyneitä kumaria selän asentoja (22-28\% havainnoista) voisi ennalta ehkäistä käyttämällä painepesuria ja jo olemassa olevia työtasoja. Esimerkiksi lypsyasemalla työskenneltäessä lypsymontussa, lypsymontun reuna on hyvä työtaso, jota voisi hyödyntää enemmänkin eri työtehtävissä. Lisäksi työskennellessä lypsymontussa lypsyvälineitä olisi hyvä säilyttää lypsyvaunussa tai lypsyliinoja sisältävän sangon voisi asettaa jonkinlaisen korkeamman jakkaran päälle, jolloin selän kumarilta asennoilta vältyttäisiin tavaroita käsiteltäessä. Lisäksi lypsyn lopputöissä painepesuria käyttäneillä selkä oli useammin suora kuin vesiletkulla pestäessä, joten painepesuri säästää selkää kuormittumasta. Vasikoiden ruokinnassa selän kumaria työasentoja oli lähes joka kolmas havainnoista. Tämä johtunee siitä, että pääosin vasikoiden juomat valmistettiin ja juoma-astiat pestiin lattiatasossa. Erityisesti näiden työvaiheiden työtasot ovat puutteellisia eli puuttuvat kokonaan. Parsien puhdistuksessa ja kuivittamisessa lähes joka kolmannessa (31\%) havainnossa selkä oli kumara, kiertynyt tai kumara/kiertynyt. Myös yläraajojen kohoasennot olivat tavallisia ( $24 \%$ havainnoista). Lantakolassa tulisi olla riittävän pitkä varsi, jotta työskentely selkä suorana olisi mahdollista. Otekorkeus varresta tulisi olla hartiatason alapuolella. Lyhytvartisen lapion käyttö parsien puhdistuksessa ohjaa selän kumariin työasentoihin. Useimmat maatalousyrittäjät kantoivat kuivikkeet saaveissa navettaan. Toimiva ratkaisu näytti olevan kuivikkeiden siirto navettaan suuremmissa erissä esim. pientraktorilla ja levitys parsiin kuivikekasasta.

Lihasten sähköisen aktiivisuuden perusteella lypsytyö kuormittaa erityisesti ranteen ojentajalihaksia. Tulos on yhdenmukainen Stålin ym. (2000) tutkimuksen kanssa. Kuormitukseen vaikuttaa raskaiden lypsyvälineiden kannattelu, vetimien kiinnittäminen utareisiin ja utareiden kuivaaminen. Tehtävät edellyttävät puristamista, samoina toistuvia liikkeitä ja ranteiden ojennusasentoja.

Maatalousyrittäjät kokivat eniten kuormitusta oikean puolen niska-hartiaseudussa iltanavetan jälkeen. Oikean dominoivan käden käyttö voi selittää rasitus tuntemuksen voimakkuutta oikealla puolen. Molempien käsien tehokkaampi käyttäminen eri työvaiheissa vähentäisi oikealle puolen kohdistuvaa kuormitusta. Miesten koettu kuormittuminen oli alhaisempaa, jota selittänee miesten alhaisemmat keskimääräiset lihasaktiivisuusarvot hartialihasten kohdalla. 


\section{Johtopäätökset}

Uusissa tuotantorakennuksissa pystytään työympäristön toiminnallisuus ottamaan paremmin huomioon kuin peruskorjatuissa. Vanhojen tuotantorakennuksen vaikeasti poistettavia ongelmia ovat mataluus, ahtaus ja sokkeloisuus. Usein vaikeutena on myös rehunjaon tehokas koneellistaminen. Jo uuden pihaton suunnitteluvaiheessa on hyvä varautua mahdolliseen myöhempään laajennustarpeeseen. Pihaton laajennusta suunniteltaessa on otettava huomioon tilan koko toiminta, jottei työn kokonaiskuormitus kasva liian suureksi.

\section{Kirjallisuus}

Ahonen, E., Venäläinen, M., Könönen, U. \& Klen, T. 1990. The physical strain of dairy farming. Ergonomics, 33(12): 1549-55.

Klemola E., Pihamaa P., Heikkilä A-M. 2000. Laajentavan lypsykarjatilan tuotannon ja työnkäytön suunnittelu. Työtehoseuran julkaisuja 375 .

Gustafsson, B., Pinzke, S. \& Isberg, P.-E. 1994. Musculoskeletal symptoms in Swedish dairy farmers. Swed J Agricultural Res, 24(4): 177-88.

Hildebrandt, V.H. 1995. Musculoskeletal symptoms and workload in 12 branches of Dutch agriculture. Ergonomics, 38(12): 2576-87.

Maatalousyrittäjien eläkelaitos. 2003. Tilastot. Saatavilla Internetissä: http://www.hci.fi/mela/tilastot.nsf

Notkola, V., Pajunen, A. \& Leino-Arjas, P. 1995. Telineet, tehdas vai toimisto - tutkimus ammattiryhmittäisestä kuolleisuudesta ja työkyvyttömyydestä. Tilastokeskus, Helsinki.

Pinzke, S. 1997. Observational methods for analyzing working postures in agriculture. J Agric Saf Health, 3(3): 16994.

Stål, M., Moritz, U., Gustafsson, B. \& Johnsson, B. 1996. Milking is a high-risk job for young females. Scand J Rehabil Med, 28(2): 95-104.

Työterveyslaitos 2003. Maatalouden työolojen kehittäminen kotieläintenhoitotyössä. Saatavilla Internetissä: http://www.ttl.fi/Internet/Suomi/TTL+toimii/Osastot/Tyoturvallisuusosasto/Tyoprosessit+ja+logistiikka/Safety+ Check+-+Tyosuojelun+tarkistuslistat.htm 